\title{
Pengaruh Model Situation-Based Learning Berbantuan Media Animasi Terhadap Kompetensi Pengetahuan Matematika Kelas IV
}

\author{
Ni Made Diana Christiawati ${ }^{1}$, I Wayan Darsana² \\ ${ }^{12}$ Prodi Pendidikan Guru Sekolah Dasar, Universitas Pendidikan Ganesha, Indonesia
}

\section{ARTICLEINFO}

Article history:

Received 18 Desember 2019

Received in revised form

30 Desember 2019

Accepted 15 Januari 2020

Available online 20

Februari 2020

\section{Kata Kunci:}

situation-based learning,

animasi, matematika

Keywords:

situation-based learning

animation, mathematics

\begin{abstract}
A B S T R A K
Penelitian ini bertujuan untuk mengetahui pengaruh model situation-based learning berbantuan media animasi terhadap kompetensi pengetahuan matematika kelas IV SDN Gugus I Gusti Ngurah Rai Kecamatan Denpasar Selatan tahun ajaran 2018/2019. Studi ini menggunakan jenis rancangan eksperimen semu dengan menggunakan desain penelitian nonequivalent control grup desaign. Populasi dalam penelitian ini adalah seluruh kelas IV SDN Gugus I Gusti Ngurah Rai yaitu sebanyak 239 siswa. Sampel penelitian ditentukan dengan menggunakan teknik random sampling. Sampel dalam penelitian ini adalah kelas IV B SDN 4 Sanur (34 siswa) sebagai kelompok eksperimen dan kelas IV SDN 3 Sanur (36 siswa) sebagai kelompok kontrol. Hasil perhitungan data gain skor ternormalisasi menunjukan nilai rata-rata kompetensi pengetahuan matematika kelompok eksperimen lebih dari rata-rata kompetensi pengetahuan matematika kelompok kontrol (eksperimen $=0,72>$ kontrol $=0,53$ ). Data kompetensi pengetahuan matematika dianalisis menggunakan uji-t dengan rumus polled varians. Kriteria pengujian pada taraf signifikansi $5 \% \mathrm{dan} d \mathrm{k}=68$. Diperoleh $\mathrm{t}_{\text {hitung }}=8,636>\mathrm{t}_{\text {tabel }}=$ 1,995 . Hal ini berarti terdapat perbedaan yang signifikan kompetensi pengetahuan matematika antara kelompok siswa yang dibelajarkan melalui model situationbased learning berbantuan media animasi dibandingkan dengan kelompok siswa yang dibelajarkan melalui pembelajaran konvensional.
\end{abstract}

\section{A B S T R A C T}

This study aims to determine the effect of the situation-based learning model assisted by animation media on the fourth grade mathematics competency of elementary school (SDN) in group I Gusti Ngurah Rai sub-district of South Denpasar in the academic year 2018/2019. This study uses quasi-experimental with nonequivalent control group design as the research design. The population in this study were all grade IV SDN group I Gusti Ngurah Rai in the academic year 2018/2019, namely 239 students. The research sample was determined using random sampling techniques. The sample in this study was grade IVB SDN 4 Sanur (34 students) as an experimental group and grade IV SDN 3 Sanur (36 students) as a control group. The results of the calculation of the data gain score normalized show the average value of the mathematical knowledge competency of the experimental group more than the average knowledge of mathematical competencies of the control group (experiment $=0.72>$ control $=0.53$ ). Hypothesis testing was analyzed using the t-test with the polled variance formula. Test criteria at a significance level of $5 \%$ and $d k=68$. Obtained $t$-count $=8.636>t$-table $=2,000$. The result means that there is a significant difference between the mathematical knowledge competencies of the groups of students taught through the situation-based learning model assisted by animation media compared to the group of students taught through conventional learning. Situation-based learning model assisted animation media has an effect on the mathematical knowledge competencies of grade IV SDN group I Gusti Ngurah Rai sub-district of South Denpasar in the academic year 2018/2019. Based on the results of the study, it is suggested that the results of this study can be used as an alternative in the learning process to help students improve the competency of mathematical knowledge by using the animation media assisted situation-based learning model.

Copyright () Universitas Pendidikan Ganesha. All rights reserved.

\section{Pendahuluan}

Pendidikan merupakan salah satu pilar yang menjadi pondasi kemajuan bangsa. Melalui pendidikan generasi penerus bangsa dapat memperoleh ilmu pengetahuan sebagai pedoman untuk berkarya dan berinovasi. Pembentukan Sumber Daya Manusia (SDM) yang berkualitas dan memiliki potensi untuk memajukan bangsa dimulai dari keterpaparan generasi muda dengan pendidikan.

\footnotetext{
1 Corresponding author.

E-mail addresses: md.diana.christiawati@undiksha.ac.id¹(Diana),iwayan.darsan@undiksha.ac.id²(Darsana)
} 
Pendidikan di Indonesia menjadi salah satu bagian yang mendapat perhatian khusus dari pemerintah. Inovasi dan gagasan kreatif terus dikembangkan untuk memaksimalkan capaian yaitu mencerdaskan generasi bangsa dan membentuk sumber daya manusia yang memiliki daya saing di tingkat internasional. Salah satu komponen dasar untuk proses belajar mengajar adalah penetapan kurikulum.

Kurikulum yang sekarang sedang diterapkan adalah kurikulum 2013 yang mampu mendorong kreatifitas siswa, karena kreatif merupakan modal yang harus dimiliki setiap siswa agar mampu mengikuti perkembangan zaman serta mencari solusi atas masalah yang dihadapi. Pembelajaran kurikulum 2013 dilaksanakan melalui pendekatan saintifik untuk memberikan pemahaman kepada siswa dalam mengenal, memahami berbagai materi menggunakan pendekatan ilmiah, bahwa informasi dapat berasal dari mana saja, tidak tergantung dari pada informasi searah dari guru. (Kurniasih \& Sani 2014:38) mendeskripsikan lima pengalaman belajar menggunakan pendekatan saintifik, "mengamati, menanya, menalar, mengasosiasi, dan mengomunikasikan". Pada intinya, pendekatan saintfik merupakan pendekatan di dalam kegiatan pembelajaran mengutamakan kreatifitas dan mengembangkan kemampuan berfikir kreatif siswa dikarenakan siswa menggali dan menemukan sendiri.

Kemampuan berfikir kreatif dapat dikembangkan melalui semua mata pelajaran yang diajarkan di sekolah. Salah satu mata pelajaran yang dapat digunakan untuk mengembangkan kemampuan berpikir kreatif adalah mata pelajaran matematika. "Kata matematika berasal dari bahasa Latin, manthanein atau mathema yang berarti belajar atau hal yang dipelajari, sedangkan dalam bahasa Belanda, matematika disebut wiskunde atau ilmu pasti, yang kesemuanya berkaitan dengan penalaran" (Susanto 2013:184). Matematika merupakan salah satu disiplin ilmu yang dapat meningkatkan kemampuan berfikir dan berargumen serta memberikan kontribusi dalam penyelesaian masalah sehari-hari. Menurut (Badan Standar Nasional Pendidikan, 2006: 147) "Standar kompetensi dan kompetensi dasar matematika dirancang untuk mengembangkan kemampuan berfikir logis, analitis, sitematis, kritis, kreatif dan kemampuan bekerjasama". Sedangkan (Menurut Susanto, 2013:184) "Standar kompetensi matematika di Sekolah Dasar yang harus dimiliki siswa setelah melakukan kegiatan pembelajaran bukanlah penguasaan matematika, namun yang diperlukan ialah dapat memahami dunia sekitar, mampu bersaing, dan berhasil dalam kehidupan". Berdasarkan penjelasan tersebut, dapat dirangkum bahwa kompetensi pengetahuan matematika di Sekolah Dasar adalah suatu ukuran yang disusun untuk mengembangkan dan mengeksplorasi kemampuan siswa baik dari sudut pandang berpikir, upaya pemecahan masalah dan kreatifitas dalam bersosialisasi yang nantinya dapat diterapkan ketika siswa mulai menemukan berbagai permasalahan di lingkungan sekitar.

Dalam meningkatkan kemampuan siswa dalam berfikir kreatif dan meningkatkan kemampuan siswa dalam memecahkan permasalahkan, dibutuhkan model pembelajaran yang melibatkan dunia nyata sebagai perantara dalam pembelajaran di kelas. Model situation-based learning merupakan model pembelajaran kontruktivitis untuk membangun konsep dengan mempelajari yang terkandung dalam suatu situasi" (Isrok'atun dan Rosmala, 2018:134). Konsep matematika yang terdiri simbol-simbol abstrak dapat dikemas melalui situasi yang ada didunia nyata dalam pembelajaran di kelas. Proses pembelajaran yang baik dapat tercipta tentunya tidak hanya didukung oleh satu komponen saja. Banyak komponen dalam pembelajaran yang bisa dikolaborasikan, salah satunya adalah pengguaan media animasi. "Media merupakan bagian dari Tekonolgi Pembelajaran dan Kemajuan dalam mengembangkan media berkontribusi positif pada pengembangan studi Teknologi Pembelajaran" (Yaumi, 2018:5). Animasi adalah gambar yang dibuat dengan menggunakan teknik tertentu sehingga gambar tersebut menjadi seakan bergerak apabila dilihat oleh mata (Aditya, 2014). Penggunaan animasi dalam pembelajaran dapat membuat pembelajaran lebih bermakna.

Berdasarkan hasil observasi pada siswa dan wawancara dengan guru wali kelas IV SDN Gugus I Gusti Ngurah Rai yang dilakukan selama 3 hari (14 - 16 Januari 2019) untuk mengetahui kondisi terkait mata pelajaran matematika diketahui bahwa penguasaan kompetensi pengetahuan matematika kelas IV SDN Gugus I Gusti Ngurah Rai masih belum mencapai target Kriteria Ketuntasan Minimal (KKM). Hasil tersebut dilihat dari nilai Ulangan Akhir Semester (UAS) siswa semester ganjil, yaitu dari 239 siswa, perolehan predikat A untuk kompetensi matematika sebanyak 9,21\%, predikat B sebanyak 34,31\%, predikat C sebanyak 46,44\% dan pedikat D sebanyak 10,04\%. Salah satu penyebab dari hasil yang ditemukan adalah kemampuan pemecahan masalah siswa yang masih kurang, siswa kurang memperhatikan guru, siswa cenderung malas bertanya, siswa kurang aktif dalam proses pembelajaran dan cenderung malas mengerjakan tugas dari guru. Secara tidak langsung pola pembelajaran tersebut membuat kompetensi pengetahuan siswa khususnya terkait pembelajaran matematika menjadi belum optimal. Salah satu strategi yang dapat diterapkan untuk meningkatkan kompetensi pengetahuan matematika yaitu dengan menerapkan model situation-based learning berbantuan media animasi. 
Model situation-based learning berbantuan media animasi merupakan suatu model pembelajaran yang komprehensif karena mengembangkan kompetensi siswa mulai dari melihat permasalahan, memahami masalah, memecahkan masalah dan mengaplikasikan permahaman yang diketahui dengan diberikan permasalahn baru. Melalui sebuah situasi yang disajikan dengan memanfaatkan perkembangan di bidang media animasi, siswa mampu menganalisis dan memecahkan permasalahan tersebut dengan kegiatan diskusi kelompok. Diskusi kelompok ini diharapkan mampu melatih siswa dalam bekerjasama dan mengekspresikan ide atau pendapat. Selain itu penggunaan media anmasi yang menarik dalam pembelajaran dapat meningkatkan rasa penasaran dan fokus siswa untuk memecahkan permasalahan. Sehingga kompetensi matematika siswa juga dapat meningkat.

Hal ini juga didukung dengan adanya penelitian yang dilakukan oleh Aqilah (2017) yang menyimpulkan bahwa terdapat perbedaan kompetensi pengetahuan matematika kelompok siswa yang dibelajarkan dengan model Situation-Based Learning, dengan siswa yang tidak dibelajarkan dengan model Situation-Based Learning. Hal ini terlihat dari rata-rata penguasaan kompetensi pengetahuan matematika pada kelompok ekperimen yaitu 67,20 dan rata-rata penguasaan kompetensi matematika pada kelompok kontrol yaitu 36,81 .

Berdasarkan uraian latar belakang tersebut, adapun tujuan yang ingin dicapai dalam penelitian ini yaitu untuk mengetahui pengaruh model Situation-Based Learning berbantuan media animasi terhadap kompetensi pengetahuan matematika kelas IV SDN Gugus I Gusti Ngurah Rai Kecamatan Denpasar Selatan Tahun Ajaran 2018/2019.

\section{Metode}

Penelitian ini dilakukan di Gugus I Gusti Ngurah Rai tahun ajaran 2018/2019. Waktu penelitian ini dilaksanakan pada bulan April sampai dengan bulan Mei 2019. Perlakuan diberikan sebanyak 6 kali di kelompok eksperimen dan 6 kali di kelompok kontrol. Jumlah perlakuan yang diberikan telah sesuai dengan jam pelajaran terkait materi dalam penelitian ini telah diatur dalam kurikulum. Studi ini menggunakan jenis rancangan eksperimen semu dengan menggunakan desain penelitian Nonequivalent Control Grup Desaign. Rancangan penelitian ini secara skematis dapat di gambarkan sebagai berikut.

\begin{tabular}{|llr|}
\hline $\mathbf{O}_{1}$ & $X$ & $\mathbf{O}_{2}$ \\
\hline $\mathbf{O}_{3}$ & & $\mathbf{O}_{4}$ \\
\hline
\end{tabular}

(Sumber: Sugiyono, 2013:79)

Gambar 1 Desain penelitian Eksperimen Semu Menggunakan "Nonequivalent Control Group Design"

Pre test diberikan untuk kelompok eksperimen dan kelompok kontrol. "Pemberian pre test biasanya digunakan untuk mengukur equivalensi atau penyetaraan kelompok" (Dantes, 2017:18). Teknik yang digunakan dalam peyetaraan kelompok adalah dengan menggunakan uji-t. Selanjutnya, peneliti memberikan perlakuan yaitu dengan memberikan model Situation-Based Learning berbantuan media animasi kepada kelompok eksperimen dan kepada kelompok kontrol dibelajarkan menggunakan pembelajaran konvensional. Kemudian setelah diberikan perlakuan, dilakukan post test untuk mengetahui kompetensi pengetahuan matematika siswa. Dari data hasil pre test dan post test diolah menjadi data gain skor ternormalisasi. Setelah diperoleh data gain skor ternormalisasi kompetensi pengetahuan matematika selanjutnya dilakukan uji prasyarat normalitas sebaran data dan uji homogenitas varians terlebih dahulu sebelum melakukan uji hipotesis menggunakan uji-t yakni dengan polled varians.

Pelaksanaan eksperimen ini terdiri dari tiga tahapan yaitu tahap persiapan, tahap pelaksanaan, dan tahap akhir eksperimen. Adapun uraian dari setiap tahapan sebagai berikut. 1) Pada tahap persiapan ini peneliti mendatangi sekolah yang menjadi sampel penelitian dengan menyampaikan surat permohonan ijin untuk melaksanakan penelitian kepada pihak sekolah. Setelah memperoleh ijin untuk melakukan penelitian, peneliti melaksanakan wawancara kepada siswa dan guru kelas yang mengajar di kelas IV dengan tujuan yaitu pertama, melakukan observasi awal. Kedua, menyusun RPP, menyiapkan bahan ajar dan menyiapkan media pembelajaran. Ketiga, menyusun instrumen penelitian untuk mengukur kompetensi pengetahuan matematika siswa. Keempat, menentukan sampel penelitian. Kelima, 
melakukan penyetaraan sampel dengan memberikan pre test. Keenam, menganalisis data pre test. Ketujuh, menentukan kelompok eksperimen dan kelompok kontrol. 2) tahapan pelaksanaan penelitian eksperimen yaitu memberikan perlakuan pada kelompok eksperimen berupa model Situation-Based Learning Berbantuan media animasi sedangkan kelompok kontrol dibelajarkan menggukan pembelajaran konvensional. Kemudian perlakuan dilakukan sebanyak 6 kali pada masing-masing kelompok, baik kelompok kontrol ataupun kelompok eksperimen. Jumlah perlakuan telah disesuaikan dengan jam pembelajaran terkait materi dalam penelitian ini yang telah diatur dalam kurikulum dan silabus. Dan 3) Tahap Akhir Eksperimen, setelah dilakukan tahap pelaksanan eksperimen, langkah selanjutnya yang dilakukan pada tahap akhir penelitian eksperimen adalah memberikan post test pada akhir eksperimen, baik untuk kelompok eksperimen maupun kelompok kontrol.

Dalam melaksanakan penelitian, peneliti terlebih dahulu harus mencari objek yang diteliti. Objek tersebut disebut dengan populasi dan sampel. "Populasi merupakan keseluruhan dari objek, orang, peristiwa, atau sejenisnya yang menjadi perhatian dan kajian dalam penelitian” (Setyosari, 2015:221). "Populasi diartikan wilayah generalisasi yang terdiri atas obyek/subjek yang mempunyai kualitas dan karakteristik tertentu yang ditetapkan oleh peneliti untuk dipelajari dan kemudian ditarik kesimpulannya untuk dijadikan sebagai sumber data dalam suatu penelitian" (Darmadi, 2014:55). Berdasarkan penjelasan tersebut, dapat dirangkum bahwa populasi adalah kumpulan obyek/subjek, orang, peristiwa atau sejenisnya yang memiliki karakteristik tertentu yang ingin diteliti oleh peneliti lalu dipelajari dan ditarik kesimpulannya untuk dijadikan sebagai sumber data dalam suatu penelitian.

Populasi dalam penelitian ini adalah seluruh kelas IV SDN Gugus I Gusti Ngurah Rai tahun ajaran 2018/2019 yang terdiri dari 7 kelas dalam 5 sekolah. Dari populasi yang telah ditentukan maka selanjutnya diambil perwakilan dari populasi tersebut yang dianggap mewakili seluruh populasi. Perwakilan dari populasi yang mewakili populasi disebut dengan sampel. "Sampel adalah suatu kelompok yang lebih kecil atau bagian dari populasi secara keseluruhan" (Setyosari, 2015:221). "Sampel adalah bagian dari jumlah dan karakteristik yang dimiliki oleh populasi tersebut" (Sugiyono 2013:81). Berdasarkan penjelasan tersebut, dapat dirangkum sampel adalah kelompok yang lebih kecil atau bagian dari populasi secara keseluruhan.

Teknik pengambilan sampel pada penelitian ini menggunakan salah satu teknik sampling, yaitu teknik random sampling sehingga setiap kelas mendapatkan peluang yang sama untuk menjadi sampel penelitian. Untuk menentukan sampel, teknik yang digunakan adalah dengan cara pengundian. Cara undian dilakukan dengan menulis semua kelas IV di seluruh SDN populasi pada masing-masing kertas yang jumlahnya 7 kelas, kemudian kertas digulung. Masukkan gulungan kertas ke dalam kotak dan lakukan pengundian untuk mendapatkan dua kelas. Dari hasil pengundian tersebut diperoleh dua kelas yang dijadikan sampel penelitian, yaitu SD Negeri 4 Sanur dan SD Negeri 3 Sanur. Kemudian dua kelas yang terpilih diberikan pre test untuk memastikan aspek kesetaraan kompetensi akademik sehingga tidak menjadi faktor perancu dalam analisis selanjutnya.

Kemudian dua kelas yang terpilih diberikan pre test untuk memastikan aspek kesetaraan kompetensi akademik sehingga tidak menjadi faktor perancu dalam analisis selanjutnya. Dalam hal ini pre test digunakan untuk menyetarakan kelompok. Apabila kedua kelompok dinyatakan setara, selanjutnya dilakukan pengundian kembali bagi kedua kelompok tersebut untuk menentukan kelas yang dijadikan kelompok eksperimen dan kelompok kontrol. Kelompok eksperimen diberikan perlakuan dengan menerapkan model Situation-Based Learning berbantuan media animasi sedangkan kelompok kontrol yang diberikan pembelajaran secara konvensional. Penyetaraan sampel dilakukan dengan menganalisis hasil pre test menggunakan Uji-t. Sebelum menguji keseteraan sampel dengan uji-t, terlebih dahulu dilakukan uji prasyarat yaitu uji normalitas sebaran data dan uji homogenitas varians.

Setelah diketahui kedua kelompok sampel setara, maka dilakukan pengundian lagi dari kedua sampel yang setara untuk memilih nama sekolah yang digunakan sebagai kelompok eksperimen dan kelompok kontrol. Dalam penelitian ini kelompok eksperimen, yaitu SD Negeri 4 Sanur sebagai kelompok eksperimen berjumlah 34 siswa dan SD Negeri 3 Sanur sebagai kelompok kontrol berjumlah 36 siswa.

Salah satu faktor yang mempengaruhi hasil penelitian adalah validitas internal. Validitas internal bersumber dari pelaksanaan penelitian itu sendiri yang berkaitan dengan perlakukan yang diberikan apakah benar-benar menyebabkan hasil yang diobservasi dalam penelitian (Setyosari, 2015). Perlakuan ini adalah faktor atau variabel dan kombinasi selain perlakuan yang dikemukakn secara terencana, yang dapat memberikan pengaruh terhadap variabel hasil. Dengan menunjukkan bahwa faktor inilah yang tidak menimbulkan dampak terhadap hal yang diobservasi dalam penelitian yang dilakukan. Kekuatan alasan yang digunakan untuk menyatakan bahwa perlakukan yang diberikan yang benar-benar menimbulkan hasil yang diamati. Validitas internal dalam penelitian ini yaitu kematangan atau maturasi 
(Maturation), pengujian sebelumnya (pretesting), instrumentasi (Intrumentation), dan seleksi yang berbeda (Differential Selection).

Kondisi eksternal dari suatu penelitian merupakan komponen yang juga perlu untuk dikendalikan. Hal tersebut berkaitan dengan validitas data diperoleh. Menurut Dantes (2017:3), "validitas eksternal menyangkut tingkat (kualitas) kerepresentatifan hasil penelitian digeneralisasikan pada populasinya".

Data yang dikumpulkan dalam penelitian diperoleh dari data pre test dan post test. Sebelum tes digunakan terlebih dahulu dilakukan validasi secara teoritis dengan menggunakan kisi-kisi dan dikonsultasikan pada ahli, selanjutnya dilakukan validasi secara empirik dengan jumlah responden 32 siswa. Dari hasil uji instrumen yang meliputi uji validitas, uji reliabilitas, uji daya beda dan uji tingkat kesukaran diperoleh 30 butir tes yang dinyatakan layak digunakan dalam penelitian dari total 40 butir tes yang di uji cobakan.

Metode dan teknik analisis data yang digunakan dalam penelitian ini adalah teknik analisis statistik inferensial. Statistik inferensial digunakan untuk menganalisis data gain skor yang dinormalisasi dari hasil pre test dan post test. Teknik yang digunakan untuk menganalisis kompetensi pengetahuan matematika dalam penelitian ini adalah dengan menggunakan analisis statistik yaitu uji-t. Dalam hal ini skor pre test juga digunakan untuk mengetahui kemampuan awal siswa. Skor pre test dan post test diambil dari sampel penelitian, yaitu kelompok eksperimen dan kelompok kontrol yang ternormalisasi dengan menggunakan rumus gain skor ternormalisasi sebagai berikut.

$\mathrm{GSn}=\frac{\text { Gain Skor }}{\text { Skor max }- \text { Skor pretest }}$

(Dantes, $2017:$ 126)

Sesudah dilakukannya uji prasyarat yang meliputi uji normalitas sebaran data dan uji homogenitas varians. Uji normalitas sebaran data dihitung dengan menggunakan Kolmogorov-Smirnov. Kriteria pengujian pada taraf signifikansi 5\%, apabila nilai maksimum $\left|F_{T}-F_{s}\right| \leq$ nilai tabel Kolmogorov-Smirnov, maka data berdistribusi normal. Sebaliknya jika nilai maksimum $\left|F_{T}-F_{s}\right|>$ nilai tabel KolmogorovSmirnov, maka data tidak berdistibusi normal. Setelah melakukan uji normalitas sebaran data dilakukan uji homogenitas varians.

Uji homogenitas varians menggunakan uji F. Kriteria pengujian pada taraf signifikansi $5 \%$ dan derajat kebebasan untuk pembilang $n_{1}-1$ serta derajat kebebasan untuk penyebut $n_{2}-1$. Jika $F_{\text {hitung }} \leq F_{\text {tabel, }}$, maka sampel dinyatakan homogen. Sedangkan jika harga $F_{\text {hitung }}>F_{\text {tabel, }}$ maka sampel dinyatakan tidak homogen. Jika data yang diperoleh sudah memenuhi prasyarat uji normalitas dan homogenitas maka dapat dianalisis yang digunakan adalah statistik parametrik. Analisis statistik yang digunakan untuk menguji hipotesis penelitian ini adalah uji beda mean (uji-t). uji Hipotesis menggunkan uji-t dengan rumus polled varians. Dengan kriteria pengujian pada taraf signifikansi $5 \%$ dengan $d k=n_{1}+n_{2}-2$. Jika harga thitung $\leq t_{\text {tabel}}$, maka $\mathrm{H}_{\mathrm{o}}$ diterima dan $\mathrm{H}_{\mathrm{a}}$ ditolak, sehingga kelompok setara dan jika harga $\mathrm{t}_{\text {hitung }}>\mathrm{t}_{\text {tabel }}$ maka $\mathrm{H}_{\mathrm{o}}$ ditolak dan $\mathrm{H}_{\mathrm{a}}$ diterima sehingga data tidak setara.

\section{Hasil Dan Pembahasan}

Hasil penelitian disajikan dalam bentuk deskripsi data kompetensi pengetahuan matematika kelas IV SDN Gugus I Gusti Ngurah Rai Kecamatan Denpasar Selatan tahun ajaran 2018/2019. Data kompetensi pengetahuan matematika diperoleh dari gain skor ternormalisasi dengan menganalisis data pre test dan post test kedua kelompok. Hasil analisis data kompetensi pengetahuan matematika kelompok siswa yang dibelajarkan melalui model situatioan-based learning berbantuan media animasi di kelas IV SDN Gugus I Gusti Ngurah Rai Kecamatan Denpasar Selatan tahun ajaran 2018/2019 disajikan dalam tabel berikut.

Tabel 01 Deskripsi Data Gain Skor Ternormalisasi Kompetensi Pengetahuan Matematika Kelompok Eksperimen

No

1

1

Data Statistik

Rata-rata (Mean
Kelompok Eksperimen

Rata-rata (Mean




\begin{tabular}{llc}
\hline 2 & Standar Deviasi & 0,09 \\
3 & Varians & 0,009 \\
4 & GSn Maksimum & 0,85 \\
5 & GSn Minimum & 0,45 \\
\hline
\end{tabular}

Berdasarkan tabel tersebut, dapat dipaparkan hasil perhitungan data gain skor ternormalisasi kompetensi pengetahuan matematika pada kelompok eksperimen yang dibelajarkan menggunakan model Situation-Based Learning berbantuan media animasi diperoleh rata-rata (mean) sebesar 0,72, standar deviasi diperoleh sebesar 0,09, varians diperoleh sebesar 0,009, GSn maksimum sebesar 0,85 dan GSn minimum sebesar 0,45.. Sesuai dengan interpretasi gain skor ternormalisasi yaitu $0,70 \leq 0,70 \leq 1,00$ sehingga kompetensi pengetahuan matematika siswa kelompok eksperimen berada pada kriteria tinggi.

Hasil analisis data kompetensi pengetahuan matematika kelompok siswa yang dibelajarkan melalui pembelajaran konvensional di kelas IV SDN Gugus I Gusti Ngurah Rai Kecamatan Denpasar Selatan tahun ajaran 2018/2019 disajikan dalam tabel berikut.

Tabel 02 Deskripsi Data Gain Skor Ternormalisasi Kompetensi Pengetahuan Matematika Kelompok Kontrol

\begin{tabular}{clc}
\hline No & Data Statistik & Kelompok Eksperimen \\
\hline 1 & Rata-rata & 0,53 \\
2 & Standar Deviasi & 0,09 \\
3 & Varians & 0,008 \\
4 & GSn Maksimum & 0,67 \\
5 & GSn Minimum & 0,33 \\
\hline
\end{tabular}

Berdasarkan tabel tersebut, dapat dipaparkan hasil perhitungan data gain skor ternormalisasi kompetensi pengetahuan matematika pada kelompok kontrol yang dibelajarkan menggunakan pembelajaran konvensional diperoleh rata-rata (mean) sebesar 0,53, standar deviasi diperoleh sebesar 0,09, varians diperoleh sebesar 0,008, GSn maksimum sebesar 0,67 dan GSn minimum sebesar 0,33. Sesuai dengan interpretasi gain skor ternormalisasi yaitu $0,70 \leq 0,70 \leq 1,00$ sehingga kompetensi pengetahuan matematika siswa kelompok kontrol berada pada kriteria sedang.

Dilihat dari nilai rata - rata gain skor ternormalisasi, siswa pada kelompok eksperimen memiliki motivasi belajar lebih tinggi dari siswa pada kelompok kontrol. Proses pembelajaran dengan penerapan Model Situation-Based Learning berbantuan media animasi membantu siswa untuk lebih memahami pembelajaran matematika dari situasi nyata yang kemudian diaplikasikan dalam materi yang diberikan oleh guru. Selain itu, kompetensi matematika siswa pada kelompok eksperimen meningkat dengan adanya kemudahan untuk mendalami konsep pemecahan masalah matematika melalui bantuan media animasi. Sedangkan kategori sedang pada kelompok kontrol menunjukan hasil bahwa siswa pada kelompok kontrol berusaha untuk mencapai penguasaan kompetensi pelajaran matematika meskipun dengan penerapan model pembelajaran konvensional.

Sebelum melakukan uji hipotesis terlebih dahulu dilakukan uji prasyarat analisis meliputi uji normalitas sebaran data dan uji homogenitas varians. Rekapitulasi hasil uji normalitas sebaran data gain skor ternormalisasi sampel penelitian disajikan dalam tabel sebagai berikut.

Tabel 03 Rekapitulasi Hasil Uji Normalitas Sebaran Data dari Data Gain Skor Ternormalisai Sampel Penelitian

\begin{tabular}{llll}
\hline No. & Sampel & Banyak & Nilai \\
Sampel & $\begin{array}{l}\text { Maksimum } \\
\left|F_{T}-F_{S}\right|\end{array}$ & $\begin{array}{l}\text { Nilai Tabel Smogorov- } \\
\text { Smirnov }\end{array}$ \\
\hline
\end{tabular}




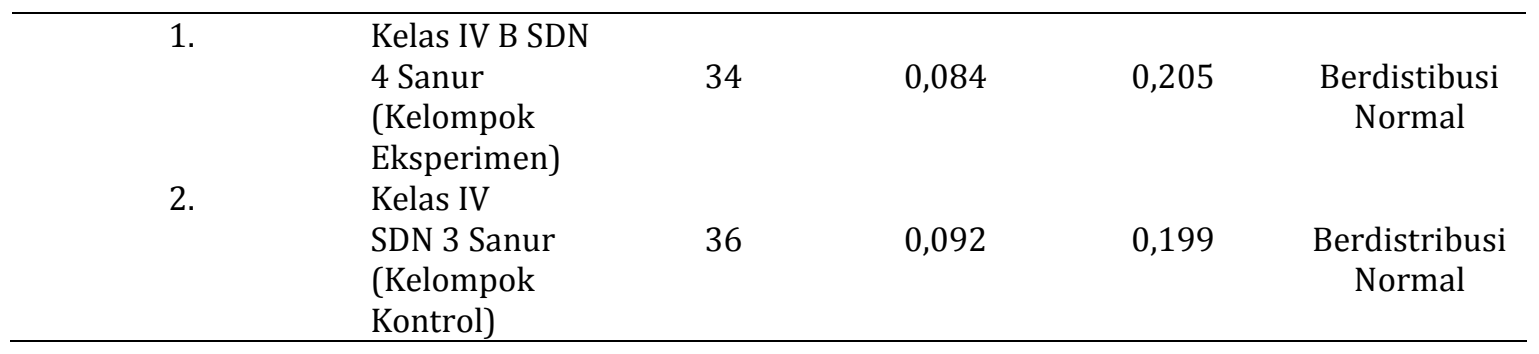

Hasil uji normalitas sebaran data kelompok eksperimen, menunjukan nilai maksimum $F_{T}-F_{s}=$ 0,084. Nilai tersebut kemudian dibandingkan dengan nilai tabel Kolmogorov-Smirnov untuk taraf signifikansi 5\% $(\alpha=0,05)$ dan N 34, sehingga diperoleh nilai tabel Kolmogorov-Smirnov, yaitu 0,205. Oleh karena nilai maksimum $\left|F_{T}-F_{s}\right|=0,084<$ nilai tabel Kolmogorov-Smirnov =0,205, maka Ho, diterima dan sebaran data gain skor ternormalisasi kompetensi pengetahuan matematika kelompok eksperimen berdistribusi normal.

Hasil uji normalitas sebaran data kelompok kontrol, diperoleh nilai masimum $\left|F_{T}-F_{S}\right|$ sebagai angka penguji normalitas, yaitu 0,092. Nilai tersebut kemudian dibandingkan dengan nilai tabel Kolmogorov-Smirnov untuk taraf signifikansi 5\% $(\alpha=0,05)$ dan N 36, sehingga diperoleh nilai tabel Kolmogorov-Smirnov, yaitu 0,199. Oleh karena nilai maksimum $\left|F_{T}-F_{s}\right|=0,092<$ nilai tabel KolmogorovSmirnov $=0,199$, maka Ho diterima dan sebaran data gain skor ternormalisasi kompetensi pengetahuan matematika kelompok kontrol berdistribusi normal.

Setelah melakukan uji normalitas sebaran data dilakukan uji homogenitas varians. Uji homogenitas varian data gain skor ternormalisasi kompetensi pengetahuan matemataika siswa dilakukan dengan menggunakan uji F.

Tabel 04 Rekapitulasi Hasil Uji Homogenitas Varians dari Data Gain Skor Ternormalisasi Sampel Penelitian.

\begin{tabular}{cllcccc}
\hline No. & Sampel & Varians & $\mathbf{d k}$ & $\mathbf{F}_{\text {hitung }}$ & $\mathbf{F}_{\text {tabel }}$ & Simpulan \\
\hline 1. & $\begin{array}{l}\text { Kelas IVB SDN 4 Sanur } \\
\text { (Kelompok }\end{array}$ & 0,009 & 33 & & & \\
& $\begin{array}{l}\text { Eksperimen) } \\
\text { Kelas IV } \\
\text { SDN 3 Sanur } \\
\text { (Kelompok Kontrol) }\end{array}$ & 0,008 & 35 & 1,13 & 1,77 & Homogen \\
& & & & \\
\hline
\end{tabular}

Hasil perhitungan diperoleh $\mathrm{F}_{\text {hitung }}=1,13$ kemudian dibandingkan dengan $\mathrm{F}_{\text {tabel }}$ pada taraf signifikansi $5 \%(\alpha=0,05)$ dengan $\mathrm{dk}$ untuk pembilang $=33 \mathrm{dan} \mathrm{dk}$ untuk penyebut $=35$, sehingga diperoleh $F_{\text {tabel }}=1,80$. Oleh karena $F_{\text {hitung }}=1,13<$ harga $F_{\text {tabel }}=1,77$, maka $H_{0}$ diterima dan varians sampel dinyatakan homogen.

Berdasarkan hasil uji prasyarat analisis yang meliputi uji normalitas sebaran data dan uji homogenitas varians, dapat diketahui bahwa data gain skor ternormalisasi pada kelompok eksperimen dan kelompok kontrol memiliki sebaran data yang berdistribusi normal dan varians yang homogen, maka dapat dilanjutkan dengan melakukan uji hipotesis statistik yaitu menggunakan uji-t. Berikut adalah rekapitulasi hasil analisis uji-t dari data Gain Skor ternormalisasi sampel penelitian sebagai berikut.

Tabel 05 Rekapitulasi Hasil Uji-t dari Data Gain Skor Ternormalisasi Sampel Penelitian

\begin{tabular}{|c|c|c|c|c|c|c|c|c|}
\hline No & Sampel & $\mathbf{N}$ & $\mathbf{d k}$ & $\bar{x}$ & $\mathbf{S}^{2}$ & $t_{\text {hitung }}$ & $t_{\text {tabel }}$ & Simpulan \\
\hline 1. & $\begin{array}{l}\text { Kelas IV B SDN } \\
\text { Sanur } \\
\text { (Kelompok } \\
\text { Eksperimen) }\end{array}$ & 34 & & 0,72 & 0,009 & & & \\
\hline
\end{tabular}




\begin{tabular}{llccccc}
\hline 2. & Kelas IV & 68 & & 8,636 & 1,995 & Ho ditolak \\
SDN 3 Sanur & & & & & & \\
(Kelompok Kontrol) & 36 & 0,53 & 0,008 & & & \\
\hline
\end{tabular}

Dari hasil perhitungan diperoleh $t_{\text {hitung }}=8,636$, kemudian dibandingkan dengan $t_{\text {tabel }}$ pada taraf signifikansi $5 \%(\alpha=0,05)$ dengan $\mathrm{dk}=68$, sehingga diperoleh $t_{\text {tabel }}=1,995$. Oleh karena $t_{\text {hitung }}=8,636>$ $\mathrm{t}_{\text {tabe }} \mathrm{l}=1,995$, maka $\mathrm{H}_{0}$ ditolak. Hal ini berarti terdapat perbedaan yang signifikan kompetensi pengetahuan matematika kelompok siswa yang dibelajarkan melalui model situation-based learning berbantuan media animasi dengan kelompok siswa yang dibelajarkan melalui pembelajaran konvensional di kelas IV SDN Gugus I Gusti Gurah Rai Kecamatan Denpasar Selatan tahun ajaran 2018/2019.

Rata-rata gain skor ternormalisasi kompetensi pengetahuan matematika kelompok eksperimen yaitu 0,72 . Sedangkan rata-rata gain skor ternormalisasi kompetensi pengetahuan matematika kelompok kontrol yaitu 0,53. Dilihat dari nilai rata - rata gain skor ternormalisasi, kelompok eksperimen berada pada interpretasi Tinggi dan rata-rata kelompok kontrol berada pada interpretasi Sedang. Siswa pada kelompok eksperimen memiliki motivasi belajar lebih tinggi dari siswa pada kelompok kontrol. Proses pembelajaran dengan penerapan Model Situation-Based Learning berbantuan media animasi membantu siswa untuk lebih memahami pembelajaran matematika dari situasi nyata yang kemudian diaplikasikan dalam materi yang diberikan oleh guru.

Kompetensi matematika siswa pada kelompok eksperimen meningkat dengan adanya kemudahan untuk mendalami konsep pemecahan masalah matematika melalui bantuan media animasi. Sedangkan kategori sedang pada kelompok kontrol menunjukan hasil bahwa siswa pada kelompok kontrol berusaha untuk mencapai penguasaan kompetensi pelajaran matematika meskipun dengan penerapan model pembelajaran konvensional. Kelemahan dalam penelitian ini salah satunya adalah adanya indikasi bahwa siswa pada kelompok kontrol mulai memahami bahwa mereka dilibatkan menjadi obyek penelitian. Hal tersebut menyebabkan siswa pada kelompok kontrol termotivasi untuk memahami setiap materi pembelajaran matematika yang disampaikan oleh guru.

Dengan demikian, model situation-based learning berbantuan media animasi dapat direkomendasikan dalam membelajaran matematika. Adapun beberapa keunggulan model situation-based learning berbantuan media animasi antara lain: 1) Siswa lebih aktif mengikuti setiap kegiatan dalam pembelajaran. 2) Siswa lebih termotivasi ketika menyelesikan permasalahan yang dimunculkan berdasarkan situasi nyata yang disampaikan melalui media yang merupakan bagian dari teknologi informasi dan komunikasi . 3) Pembelajaran situation-based learning berbantuan media animasi dilakukan dengan pembelajaran berkelompok sehingga dapat melatih siswa untuk bekerjasama dan menjadi tutor sebaya. 4) Melatih kemampuan melihat situasi berkaitan dengan permasalahan sehari-hari.

Hasil temuan pada penelitian ini memiliki persamaan dengan penelitian sebelumnya yang relevan dan memperkuat hasil penelitian yang diperoleh hal tersebut didukung hasil penelitian yang diajukan oleh Isrok'atun (2015) dan Larawati (2016) yang sama-sama membuktikan bahwa kompetensi pengetahuan pada kelompok eksperimen yang dibelajarkan menggunakan model situation-based learning lebih baik daripada kompetensi pengetahuan pada kelompok kontrol yang dibelajarkan menggunakan pembelajaran konvensional.

Berdasarkan pemaparan tersebut, dapat disimpulkan bahwa pembelajaran menggunakan model situationbased learning berbantuan media animasi dalam penelitian ini berpengaruh terhadap kompetensi pengetahuan matematika kelas IV SDN Gugus I Gusti Ngurah Rai tahun pelajaran 2018/2019 Kecamatan Denpasar Selatan. 


\section{Simpulan Dan Saran}

Berdasarkan analisis data dan pembahasan tersebut dapat disimpulkan bahwa model pembelajaran model Situation-Based Learning berbantuan media animasi berpengaruh terhadap kompetensi pengetahuan matematika siswa kelas IV SDN Gugus I Gusti Ngurah Rai tahun ajaran 2018/2019. Hal ini terbukti dari hasil analisis data menunjukkan $t_{\text {hitung }}=8,636>t_{\text {tabel }}=1,995$ pada taraf signikansi $5 \%$ ( $\alpha$ $=0,05$ ) dengan $\mathrm{dk}=68 \mathrm{dan}$ diperoleh perhitungan data gain skor ternormalisasi kompetensi pengetahuan matematika menunjukkan rata-rata kompetensi pengetahuan matematika siswa kelompok eksperimen lebih dari rata-rata kompetensi pengetahuan matematika siswa kelompok kontrol $(\overline{\mathrm{X}}$ eksperimen $=0,72>$ $\overline{\mathrm{X}}$ kontrol $=0,53$ ).

Saran yang dapat diajukan yakni, kepada guru, agar lebih kreatif untuk memberikan fasilitas berupa sumber belajar dan kesempatan yang lebih besar bagi siswa pada pembelajaran dengan menggunkan model situation-based learning berbantuan media animasi sehingga tercipta pembelajaran bermakna dan menyenangkan bagi siswa. Kepada kepala sekolah , agar dapat menggukan hasil penelitian ini sebagai pendukung sumber belajar guru dalam meningkatkan kualitas pembelajaran dengan menciptakan pembelajaran yang menyenangkan di sekolah sehingga mampu menghasilkan siswa yang berkualitas. Kepada peneliti lain, agar hasil penelitian ini digunakan sebagai referensi untuk melaksanakan penelitian selanjutnya atau menemukan inovasi kegiatan pembelajaran lainnya yang bermakna dan menyenangkan bagi siswa.

\section{Daftar Rujukan}

Aditya, I Km. Ngurah Budi (2014). "Pembelajaran Berbasis Komunikatif Berbantuan Media Animasi Berpengaruh Terhadap Hasil Belajar Matematika Siswa Kelas V SD Negeri Gugus V Kecamatan Karangasem". Jurusan Pendidikan Guru Sekolah Dasar FIP Undiksha, Volume 2, Nomor https://ejournal.undiksha.ac.id/index.php/JPGSD/article/download/2151/1869 (diakses tanggal 12 Maret 2019).

Aqilah, Benazir, dkk (2017). “Situation-Based Learning Dalam Upaya Meningkatkan Kemampuan Creative Problem Solving Matematis Siswa Pada Materi Bilangan Bulat”. Jurusan Pendidikan Guru Sekolah Dasar UPI Semedang. Volume 2, Nomor 1 (hlm.1001-1010). http://ejournal.upi.edu/index.php/penailmiah/article/viewFile/2933/1961 (diakses tanggal 25 Januari 2019).

Badan Standar Nasional Pendidikan. 2006. Standar Isi Untuk Satuan Pendidikan Dasar dan Menengah. Jakarta: Badan Standar Nasional Pendidikan. Tersedia pada https://masdwijanto.files.wordpress.com/2011/03/buku-standar-isi-smp,pdf (diakses pada tanggal 12 Februari 2019).

Darmadi, Hamid. 2014. Metode Penelitian Pendidikan dan Sosial. Bandung: Alfabeta.

Isrok'atun, dan Rosmala, Amelia. 2018. Model-Model Pembelajaran Matematika. Bandung: PT. Bumi Aksara.

Isrok'atun. (2015). “Enhacing Students' Mathematical Creative Problem Solving Ability Through SituationBased Learning In Elementary School". Indonesia University of Education. Volume 3 Nomor 9 (hal. 73-80). http://www.ijern.com/journal/2015/September-2015/06.pdf (diakses tanggal 28 Januari 2019).

Larawati, Intan, dkk (2016). "Penerapan Model Situation-Based Learning Pada Materi Sifat-sifat dan Jaring-jaring Bangun Ruang Sederhana Di Kelas IV SDN Paseh 1 Sumedang". Jurusan Pendidikan Guru Sekolah Dasar UPI Semedang. Volume 1 Nomor 1. (hal. 71-80) http://ejournal.upi.edu/index.php/penailmiah/article/viewFile/2933/1961 (Diakses tanggal 25 Januari 2019).

Dantes, N. 2017. Desain Eksperimen dan Analsiis Data. Depok: PT Raja Grafindo. 
Setyosari, Punaji. 2015. Metode Penelitian Pendidikan \& Pengembangan. Jakarta: Kencana.

Sugiyono. 2013. Metode Penelitian Kuantitatif Kualitatif Dan R \& D. Bandung: Alfabeta.

Susanto, Ahmad. 2013. Teori Belajar dan Pembelajaran di Sekolah Dasar. Jakarta: Kencana.

Yaumi, Muhammad. 2018. Media dan Teknologi Pembelajaran. Makasar: Kencana.

Kurniasih, Imas dan Berlin Sani. 2014. Sukses Mengimplementasikan Kurikulum 2013. Surabaya: Kata Pena. 